\title{
SELF-CONCEALMENT IN JEAN WEBSTER'S DADDY LONG LEGS
}

\author{
Fania Hasri Fitranti ${ }^{1}$, Mamik Tri Wedawati ${ }^{2}$ \\ English Department, Universitas Negeri Surabaya \\ Jl. Lidah Wetan, Lidah Wetan, Kec. Lakarsantri, Kota SBY, Jawa Timur 60213, Indonesia \\ fania.17020154056@mhs.unesa.ac.id ${ }^{1}$,mamikwedawati@unesa.ac.id ${ }^{2}$
}

\begin{abstract}
This research studied the self-concealment of the main character in Daddy Long Legs novel. It is aimed at identifying self-concealment through the main character's Johari Windows. This research also described fear of self-disclosure. The method used is descriptivequalitative research. This analysis is collaborating the concept of self-concealment with Johari Window. The results showed, Judy Abbott, the main character does self-concealment which is identified by the most dominated hidden area in her Johari Window which is including fear of self-disclosure. By comparing with previous self-concealment analysis in some literary studies, it is found that self-concealment is connected with queerness, deception, and either repression or suppression defense mechanism.
\end{abstract}

Keywords: Self-Concealment; Johari Window; Hidden Area; Self-Disclosure.

\begin{abstract}
ABSTRAK
Penelitian ini mempelajari penyembunyian diri tokoh utama dalam novel Daddy Long Legs. Penelitian ni bertujuan untuk mengidentifikasi penyembunyian diri melalui karakter utama Johari Windows. Penelitian ini juga mendeskripsikan rasa takut akan keterbukaan diri. Metode yang digunakan adalah penelitian deskriptif-kualitatif. Analisis ini mengkolaborasikan konsep penyembunyian diri dengan Johari Window. Hasil penelitian menunjukkan, Judy Abbott, tokoh utama melakukan penyembunyian diri yang diidentifikasikan dengan area tersembunyi paling dominan di Johari Window-nya yang termasuk rasa takut akan keterbukaan diri. Dengan membandingkan dengan analisis penyembunyian diri sebelumnya dalam beberapa studi sastra, ditemukan bahwa penyembunyian diri terkait dengan keanehan, penipuan, dan mekanisme pertahanan represi atau penindasan.
\end{abstract}

Kata kunci: Penyembunyian Diri; Jendela Johari; Area Tersembunyi; Keterbukaan Diri.

\section{INTRODUCTION}

It is not surprising if humans, as dynamic creatures are having many ways to present who they are. However, those ways of presenting themselves are often dependent on some selections from the part of the self. Some humans are not free when showing their selves. They may have a stigmatized identity which may create fear of self-disclosure, then lead them to do self-concealment (Chaudoir \& Fisher, 2010; Cruddas, Gilbert, \& McEwan, 2012; Larson, Chastain, Hoyt, \& Ayzenberg, 2015). Besides stigmatized identity, self-concealment also occurs in somebody who 
has a traumatic event (Larson \& Chastain, 1990) and somebody who gets exclusion in a certain place (Zhou, King, Gjorgiovska, Mihajlov, \& Stojanovski, 2019).

This study of self-concealment is focused on the main character in Daddy Long Legs; an epistolary novel that contains daily letters from the main character whose obligation to send them to the mysterious benefactor who has schooled her into higher education. Jerusha Abbott, the main character who has summoned, is an adolescent now not under the care of the orphanage because she goes to a "woman only' college. At college, she must adapt to her new environment. Mainly, she must get used to befriend her dormitory roommates who are girls from the upper class. Knowing that she is just a 'poor' ex-orphanage with no family-related, this contrast condition makes her being a minority, feeling excluded, remembering past trauma at an orphanage, and holding a grudge towards her stigmatized identity - every surrounded with her friends. So, she begins to conceal her actual identity by starting from changing her front name from Jerusha into Judy, creating fake information about live-place and ancestry, until faking her identity by pretending that she is not an ex-orphanage. This conscious behavior of self-concealment happens through her college years, then it also interrupts her love life.

None of any studies has applied self-concealment as a topic discussion to examine Daddy Long Legs. But it is available in other qualitative psychoanalysis studies. Khasanah in Coping Behavior for Unhappy Childhood in Jean Webster's Daddy Long Legs (1912): An Individual Psychological Perspective (2014) explores the actions of Judy Abbott's coping unhappy childhood by using Adler's psychology theory. Through library research, this qualitative study results that trauma treatment for coping with unhappy childhood can be achieved through creative-self. This study only covers Judy's escape with no self-concealment has been discussed. Another psychoanalysis study, Wiresti in The Main Character's Personality Development in Jean Webster's Novel "Daddy Long Legs": A Psychological Study (2018) uses Sigmund Freud (id, ego, and superego) psychological approach to analyze Judy Abbott, which resulting that it is available rapid change of Judy's personal development. But it does not cover the discussion that connected with selfconcealment and the theory used is old school enough. While in social approach, Hollander in The Fabian Child: English and American Literature and Socialist Reform, 1884-1915 (2015) convey Fabian socialism, the oldest political association in Britain - is deeply inspiring Jean Webster's political view and her references for writing novels, especially Daddy Long Legs. It is a qualitative study with library research that provided hints refers to Fabian. This study resulted if Judy Abbott's political view is authorized by Jean Webster's leftist. This study mainly connects the author's political view into novel characterization. But this study is limited in the political view only. Moreover, this study covers discussion about other Fabian writers.

Although it is none in the Daddy Long Legs analysis, self-concealment is quietly popular in other literary studies. Sangeetha in Concealment as a Tool of 
Deception: An Analysis of J. K. Rowling's Harry Potter and the Chamber of Secrets (2017) examines a qualitative study about the benefits of doing self-concealment in some characters of the first Harry Potter novel; Harry Potter and the Chamber of Secrets - and its writer. The result claims that each character examined is doing conscious self-concealment to smooth their motives and acts. On the other hand, Novenia in Elio's Defense Mechanisms in Concealing His Homosexuality in André Aciman's Call Me By Your Name (2019) with her qualitative study of selfconcealment in Elio, a homosexual man from Call Me by Your Name - results that self-concealment takes form in unconscious defense mechanism, as repression. However, instead of available in magical witches and homosexual men, another queerness attached with self-concealment is also represented in a vampire. Here, Oakley in "I Could Kill You Quite Easily, Bella, Simply by Accident."*: Violence and Romance in Stephenie Meyer's "Twilight" Saga (2012), applies the qualitative study of a postmodern feminist framework which is pointed to the female protagonist main character in Twilight Saga. Although self-concealment is not the main part of this study, it is sufficient to vote that self-concealment is strongly attached to somebody's queerness, they who are included in the minority.

The motives and queerness or alienated self of Judy Abbott lead this study of self-concealment. With the research question of how is Judy's self-concealment formed, this study is aimed to describe the self-concealment forming through the main character's Johari Window. The benefit from this study is at filling the opportunity to enlarge perspective on a theoretical level for further study below the works of Jean Webster. While on a practical level, this study is useful to increase comprehension in self-awareness.

\section{LITERATURE REVIEW}

Being a popular topic in psychology studies, self-concealment is also often used for literary studies. In the literary study, self-concealment is used either as an independent concept or collaborated with other theories. Self-concealment as an independent concept is applied in the study of Harry Potter and the Chamber of Secrets' certain characters analysis (Sangeetha, 2017). This study wraps concealment as a manifestation of characters' motives and things. For example, is Tom Riddle's motives and invisible cloak. It is focused on the result that self-concealment is followed with deception. Another is the study of a vampire's self-concealment in the Twilight Saga (Oakley, 2012). There, self-concealment is not only available as a supporting finding, but is also giving a result that self-concealment of a vampire is for disguising the self, so he can adapt with human. While self-concealment collaboration with other theories is available in the study of Call Me by Your Name homosexual character. Collaborating self-concealment with Freud's anxiety theory, the result shows that the self-concealment of a homosexual man is categorized as repression. Repression itself is an unconscious act of somebody to distress their trauma (Novenia, 2019). This is quietly different from two previous studies which assumed 
that self-concealment is the conscious one or can be called suppression (Sangeetha, 2017). Both repression and suppression are branches of defense mechanism, developed by Anna Freud, the daughter of Sigmund Freud. Besides how the theory applies and what the results are, self-concealment can be concluded if it follows somebody with queerness. From those studies above the queerness is common with wizards and witches, vampires, also homosexual men. Self-concealment may be available in an ex-orphanage who feels alienated.

Self-concealment is considered as part of personality. It is an act for hiding distressing information from others actively. According to Larson and Chastain - two researchers the most contributed in self-concealment stated that the concealed information employed in self-concealment has three characteristics; it is private and informal, deliberately accessible, intentionally concealed (Larson \& Chastain, 1990). Thus the operation of self-concealment is divided into three (1) a desire to keep things for oneself, (2) to avoid personal sharing of secrecy or unfavorable information, and (3) to be cautious of the disclosure of personal information concealed (Cruddas et al., 2012). Self-concealment is highly correlated with selfdisclosure then in latest Larson's and Chastain's Self-Concealment: Integrative Review and Working Model (2015), self-concealment is manifested as suppression which is available in the construction of fear of self-disclosure.

Fear of self-disclosure is a chronic fear and hesitation over the personal secrets revelation to others (Rose Ragins, Singh, \& Cornwell, 2007). It is a part of self-disclosure which can be portrayed with Johari Window. Johari Window is a theory about interpersonal behavior and awareness that set in four panels which are invented by Joseph Luft and Harry Ingham (1969). The original model of the Johari Window is available in Graph 1.

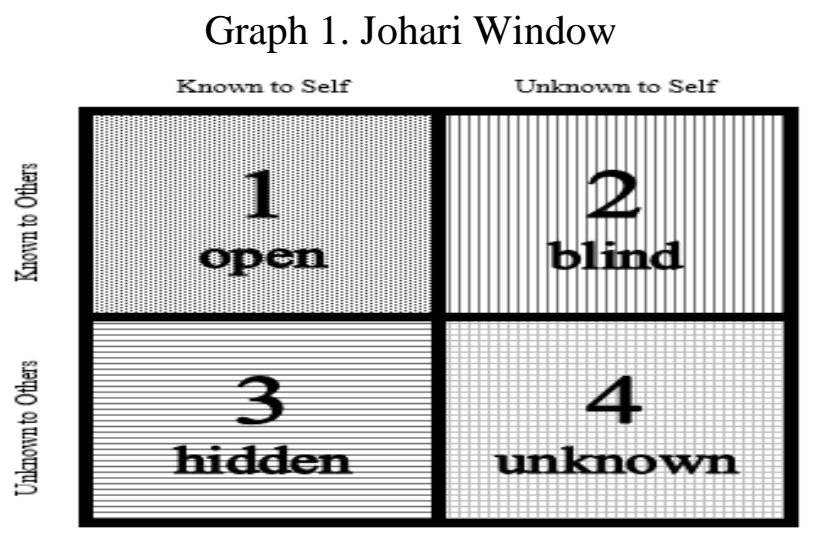

Quadrant 1 (Q1) is the open area that refers to an individual's personal information known by self and others. Quadrant $2(\mathrm{Q} 2)$ is the blind area that refers to an individual's personal information known to others but unknown by self. Quadrant 3 (Q3) is the hidden area that refers to an individual's personal information known by self, but unknown by others. Quadrant $4(\mathrm{Q} 4)$ is the unknown area that refers to an individual's future capabilities that can be discovered in the future time. The 
unknown area is unknown both by the self or the others. Each quadrant or area can increase or decrease itself. It depends on what process is going on the owner of Johari Window. Below, Graph 2 is an example of few processes to make expansion through disclosure, discovery, feedback solicitation, and observation.

Graph 2. The Expansion of The Johari Window

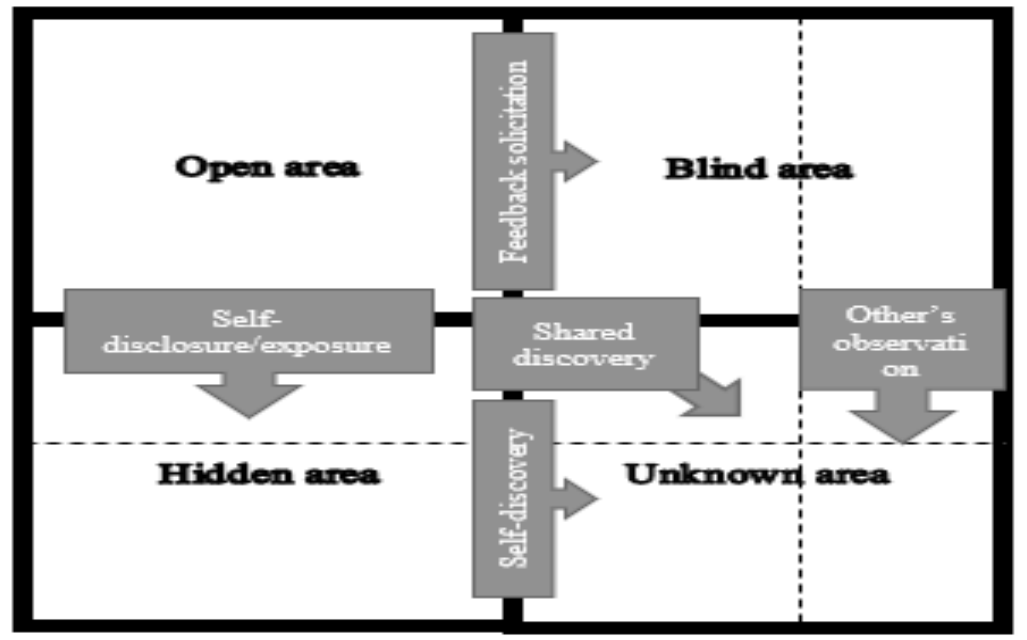

\section{RESEARCH METHOD}

This study used a qualitative descriptive approach. This is a method to describe patterns and themes of a certain condition in life to find the answer descriptively. The qualitative descriptive approach aims to closely analyze a condition to uncover relationships and correlations concerning life events where the specific condition is questioned. It is an inductive methodology that seeks to achieve a better understanding of the perspective of an individual or community (Parse \& Nursing, 2001). The primary data were taken from Jean Webster's Daddy Long Legs novel published in 2017 by Gramedia Pustaka Utama, Jakarta, in its English Classic collections. The first printing was published in 1912 by The Century Co, New York. The study selected Judy's pieces of dialogues, monologues, sentences, and phrases in her letters which related to concepts and theories - which are available in her junior year, sophomore, third year, and last year in college. While, the sources of supporting data were taken from the books, relatable journal, and internet sources which were relevant to the topic of this study.

The primary data collection was held through intensive reading. There were three steps for it. The first was reading whole data sources. There are so many data founded which were related to the topic of this study. So, this led to the second step which was held by selecting the data which were most needed. The third step was grouping certain data according to analyzing planning. While the secondary data collection was firstly held by quick reading. If the data sources founded were appropriate with primary data and related topic, it was continued with intensive 
reading, then selected data is used to vote primary data.

The analysis to identify Judy's self-concealment was held by several steps. The first step was placing some prominent points which were founded from the primary data into the first or initial Johari Window. This meant that the points in Judy's Johari Windows were based on the data which contained her sentences. This was also important to know the basic form of Johari Window with the same size of each panel, before deciding to expand certain panels to get the final results. The second was descriptively explaining the cause and reason between the points and the data. The third was to with some events or condition of Judy's self which were proofed with data founded. From this relating process, the certain area will develop to increase or decrease its size and how it might be layering other areas. Then the final result of Judy's Johari Window with which one the layer has the widest area could be identified as her self-concealment. Judy's self-concealment would be related and compared with some previous studies with the same topic, to know the pro and contra of the findings. However, the last step was stating the contribution and concluding the conclusion.

\section{FINDING AND DISCUSSION}

\section{Finding}

\section{Initial Johari Window}

Johari Window is worked by collecting all information about the self, considering on what personal information is suited to be placed in each area, making wider or narrower certain area - depended either on self-disclosure or concealment, and the widest area of Johari Window will give the final result, telling what the dominant one is. Knowing that Johari Window requires information that must be placed in an initial form, close reading has been resulting that the first panel refers to Judy's writing passion and her identity; the second panel refers to Judy's silly side which is perceived by her friends, and friends' thoughts about Judy; the third panel consisted of Judy's secretive personal information, including her feeling towards Jervis Pendleton and hatred towards Pendleton family; then the fourth panel consisted of Judy Abbott's capabilities which can be revealed or achieved in the future including her path into a future writer. The findings and placement are available in Graph 3. 
Graph 3. Judy's Initial Johari Window

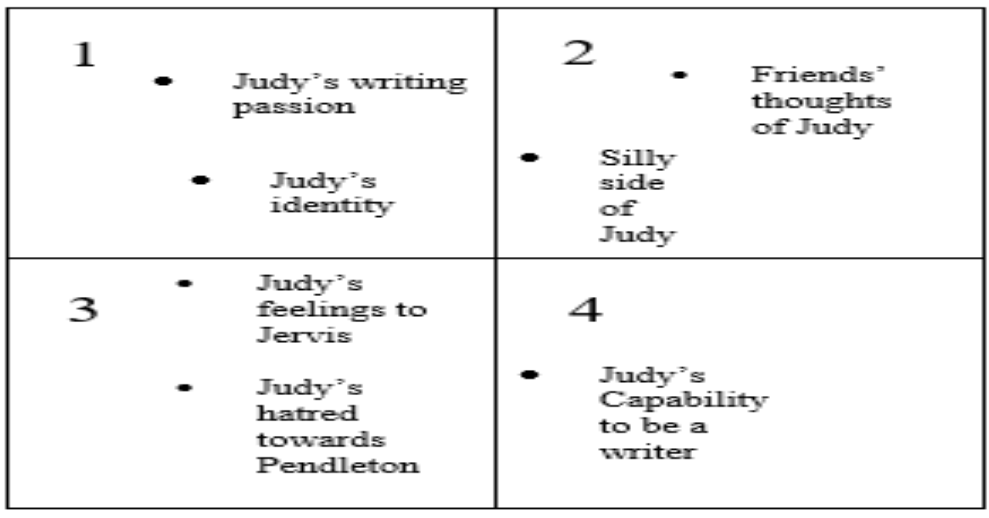

\section{a. The Open Area}

In graph 3, the first panel is an open area that contains Judy's writing passion and identity. The reason why both must be placed in the open area is Judy's proudness and disclosure can be proofed from her statements which said that she had won a $\$ 25$ prize from the annual short-story contest that the Monthly held (Webster, 2017, p. 109). At the beginning of her journey as a student in college, Judy was very proud of her writing publication in Monthly, a college magazine. This is proven by her announcement of winning. This means that she was unconsciously disclosing information about things that honored her. There is almost no shame in doing something favorable and profitable, for Judy. Because she kept continuing her writing passion in her following years. This is proven by her first story publication which cost $\$ 50$ (Webster, 2017, p. 130). Then, she became editor in the Monthly, a college magazine, in her senior year (Webster, 2017, p. 160).

After her writing passion proudness, there is Judy's identity disclosure in the open area, in Graph 3. The reason for putting identity in the open area is based on people's common acts. Almost everybody will disclose their basic personal information which is about names, occupations, addresses, families, etc. Judy surely opens about her new identity. She told Sallie McBride, her roommates, that her mother and father had died, then such a kind of gentleman was sending her to college. Although, she was brought up in an asylum. (Webster, 2017, p. 30). Based on the evidence, Judy lied about her family background. Although she was lying, this is still able to be considered as her disclosure of basic identity. So, it is suited to be placed in an open area.

\section{b. The Blind Area}

In Graph 3, the second panel or Judy's blind area contains her silly side perceived by friends and also their other thoughts about Judy. In the blind area, Judy knew nothing about what people hide inside, especially all things related to her. The proof is available when she and her roommate, Julia, were on a train and getting negro waiters. Then Judy got surprised because she never knew about meals being 
served in trains. Her act of being surprised began to trigger Julia's curiosity. So, Julia came out with a question "Where on the earth were you brought up?" said Julia to Judy (Webster, 2017, p. 96). The curiosity of Julia implies that she hid her perception of Judy. Then, Judy's silly side is exposed from her strangeness after what she said.

By confessing about the first time of seeing negro waiters on the train, Judy triggered Julia to think about how silly Judy was, for not knowing this simple ordinary thing. It results in the existence of Judy's silly side in the blind area of Johari Window. Other evidence of Judy's silly side is depicted from how her friends react after Judy's ignorance. This is proofed by the statement which told that Judy thought if Michael Angelo is an archangel (Webster, 2017, p. 25). Then also when her friends talked about Maurice Maeterlinck, and Judy asked whether she was a Freshman. This created jokes, then they had gone all over college (Webster, 2017, p. 26). Michael Angelo and Maurice Maeterlinck were popular public figures among Judy's college friends. Again, Judy's ignorance or her lack of knowledge is successfully creating her silly side perceived by her friends, resulting in laughs and jokes. However, knowing the statement that the joke about Judy's ignorance had gone over college, there will be possibilities for her friends to pop out other perceptions or thoughts about Judy which are undiscovered yet by Judy.

\section{c. The Hidden Area}

In Graph 3, the third panel or Judy's hidden area refers to things she has no intention to disclose. The hidden area of Judy's Johari Window consisted of her feelings towards Jervis Pendleton and hatred toward his family. However, Jervis Pendleton is Judy's lover. They were loving each other, but Judy did not consider disclosing any sign because she had a complicated feeling with her hatred towards Jervis' family. The evidence of Judy's feelings towards Jervis is available when she realized that her letter to Daddy Long Legs was full of Mater Jervis (Webster, 2017, p. 185). This is also available in the proof that Judy did not want to marry Jervis Pendleton, because she felt that she lacked antecedents. It did not seem right for her, compared to the family of his (Webster, 2017, p. 186). Those are pieces of evidence that tell if Judy Abbott secretly loved Jervis. She forced herself to hide her feelings because of remembering who she was. She stamped herself as somebody whose lack of antecedents, contrasted to Jervis with his noble family.

The very deep down of Judy's hidden area is her hating towards Pendleton. This is complicated but in one line from why she rejects her beloved one. Below are some captures of Judy's exaggerated self, forcing her to hate the Pendleton family because of their contrast-ness with Judy's true background. A very different life between a brought-up and a foundling. Judy said that she and Julia are destined to be enemies (Webster, 2017, p. 27). This is also proven by Judy's revenge on the silk stocking. She got mad after Julia wore silk stockings then sat cross-legged in Judy's room to do geometry homework. So, she planned to buy some silk stockings, too (Webster, 2017, p. 40). Judy also got triggered by Julia's question about what Judy's mother's maiden name was. Then, Judy stated it as such an impertinent question to 
ask of a person from a foundling asylum (Webster, 2017, p. 44). However, a question of asking her original mother's name - from Julia Pendleton who did not know if Judy was grown up in an orphanage - is pretty normal. But Judy was too sensitive for having conversations with a person who came from a rich family, especially because of their opposite lifestyle, comparing to her. Plus, Julia's rudeness in showing off her silk stocking had triggered Judy to be secretly hating her.

\section{d. The Unknown Area}

In Graph 3, the fourth panel or Judy's unknown area is consisted of her capability to be a writer. Johari Window categorizes the unknown area as a panel for guessing future capability. Based on the evidence, the most real capability which can be captured from Judy's self is her writing career path. She got rejection after sending her novel to the publisher, then the editor returned it with a note, "Plot highly improbable. Characterization exaggerated. Conversation unnatural. A good deal of humor but not always in the best of taste. Tell her to keep on trying, and in time she may produce a real book." (Webster, 2017, p. 162). Advice from the publisher's editor that told Judy to keep trying is implying that she had a capability to be a real writer at a later time. There are also other capabilities in infinite unknown which have not been exposed by Judy.

\section{The Open Area and Hidden Area Expansion}

Graph 3 has portrayed Judy's Johari Window in its initial form. Judy got such development on disclosure and concealment during her years in college. It is including how she manages her identity. Those processes are influencing the width of each panel in Johari Window. Below is Graph 4, it is showing that the open area expands its width, so is layering the blind area.

Graph 4. The Open Area Expansion of Judy's Johari Window

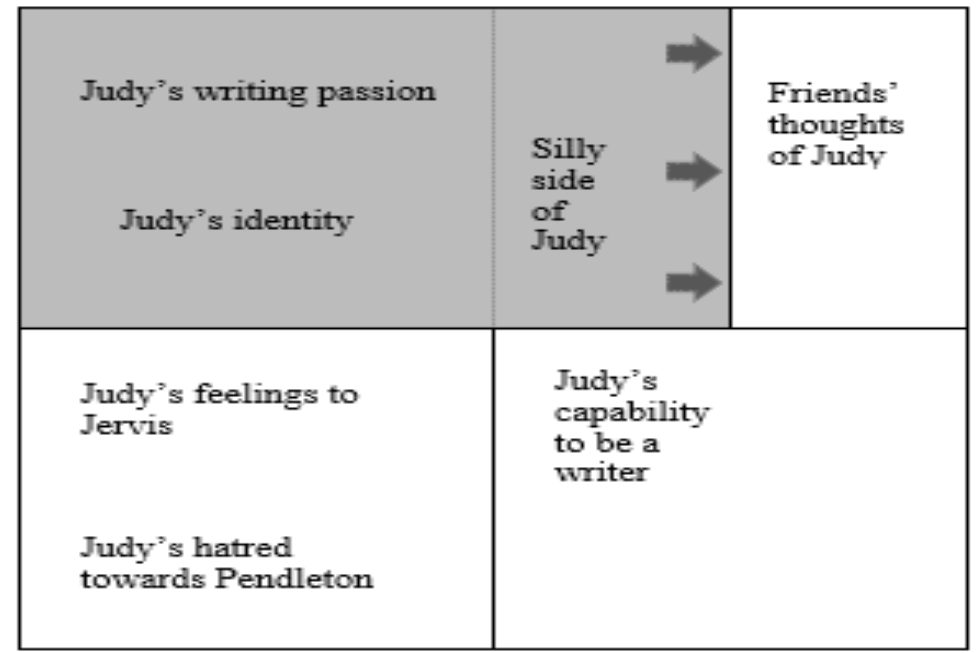

Graph 4 shows Judy's disclosure. The open area now is expanding the blind area because of information exchange. The information exchange happens when 
somebody discovers what others think about them. In Judy's case, she had discovered her friends' perception about her silly side. It is proofed by her knowing that the jokes of not knowing Michael Angelo and Maurice Maeterlinck had spread among college friends (Webster, 2017, p. 25).

But, besides unconsciously disclosing her silly side, Judy also tried to conceal it. It is a hint that Judy suffered a fear of self-disclosure. This is signed by her attempt of concealing her silly side which had been done by gaining some knowledge she needed, to fix her reputation. This is proofed by her confession that she must read any plain books to conceal her ignorance. Judy's said the reason for doing it is just 'because there are eighteen blank years' behind her (Webster, 2017, p. 36). The eighteen blank years mean Judy's lifetime in the orphanage. While the plain books mean poems and novels which were commonly known by almost Judy's college friends. For instances are Tennyson's poems, Vanity Fair, Kipling's Plain Tales, and especially Little Women. Judy with her grudge stated that if someday somebody mentioned 'pickled limes', she would know what her friends were talking about (Webster, 2017, p. 37). The worry of being stamped as queer makes Judy hide this act to fix her silly reputation. Judy hides the fact that she struggles to catch some common knowledge that college girls must use to know, by reading plain books every overnight. The pickled limes that Judy mention is a substance in the novel she reads, Little Women. She was in progress to conceal her silly reputation, especially ignorance. This concealment makes hidden to expand as Graph 5 shows. Below, Graph 5 does not only show the hidden area expansion through Judy's silly side but also her identity and capability.

Graph 5. The Hidden Area Expansion of Judy's Johari Window

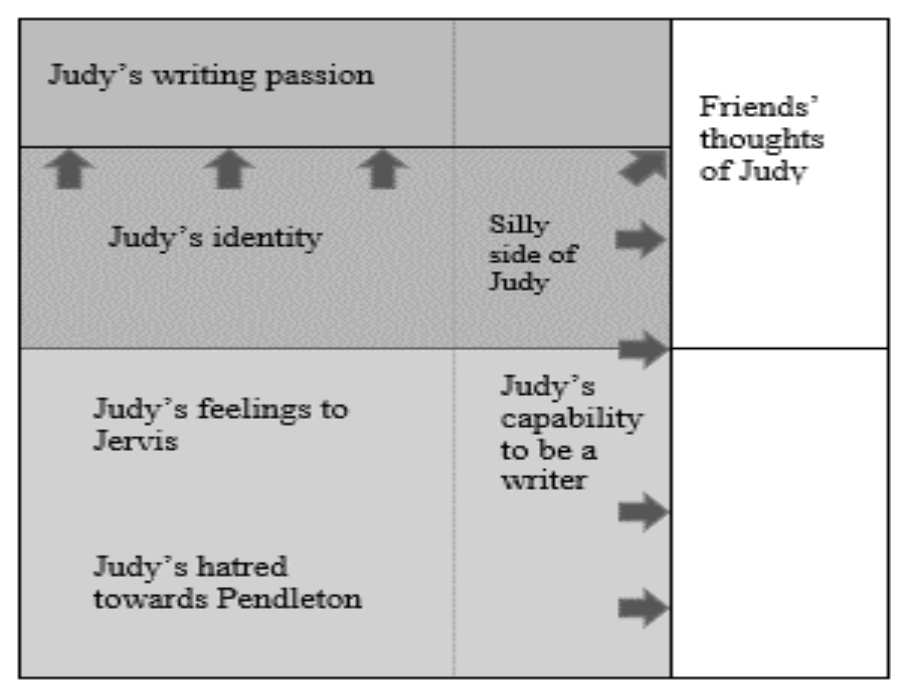

In Graph 5, Judy's identity is included in the expansion of the hidden area. This is because her disclosure of a new faked identity is considered useless. She served identity deception and never opens about her true identity which lies her truth 
that she is an ex-orphanage. Judy ever claimed that her true identity was very hard to handle because of her easily bursting. She used metaphor to describe her situation. "Before I thought, I started to tell the others what an experience I was having. The cat was almost out of the bag when I grabbed it by tails and put it back" (Webster, 2017, p. 41). Her confusing on managing identity is portrayed through metaphor that it is like grabbing a cat's tail and put it back in the bag. It means that complications between her self-disclosure and self-concealment had confused her. Another thing included in the expansion of the hidden area is Judy's capability to be a writer. Actually, this is not too important for Judy's self-concealment. Because she was unconsciously discovering her capability to be a writer, but she did not have an intention to share it, moreover there were not motives to hide it. It was just commonly saved by herself. Judy's symptoms in disclosing and concealing are also positively intended if she has deception which is started by suppression.

\section{Discussion}

Based on the findings above, there are three Johari Windows alongside Judy's development. Yet, the findings divide them into two sections. This is because the initial Johari Window is the basic result that continues to develop into the next two. It is also because the proofs for the expansion of the open and hidden areas in the second and the third Johari Window are relating to each other.

The findings of three Johari Windows refer that Judy had fear of selfdisclosure. Judy's fear of self-disclosure actually can be identified from the open area in the first or the initial Johari Window. The finding shows that in the open area, Judy disclosed her fake identity and good things like writing passion. This means that she had a fear of self-disclosure because she only suppressed the distressing personal information of herself by providing a new faked identity.

Judy's fear of self-disclosure is also identified by how the open area expansion in the second Johari Window becomes half layered by the hidden area expansion in the third. This bi-layered area of open and hidden area is containing her identity and silly side. In the first and the second Johari Window, Judy disclosed a new fake identity as disclosure, but it is nonsense because she actually hid the true identity. So, this is the reason why it is included in the hidden area expansion in the third Johari Window. In this case, Judy created identity substitution which can be categorized as a deception. This deception exists because Judy feared disclosing her true self. While the cause why Judy's silly side is now layered by the hidden area after the open area expansion is because after knowing her silliness from friends' perception, she suppressed it by doing some chores like reading plain books. This is her struggle to be 'normal'. Judy feared to disclose because she remembered the shame of being silly after her ignorance and lack of knowledge.

Judy's fear of self-disclosure also occurs in the hidden area. However, the hidden area remains still the same with no interruption by other area expansion in all three Johari Windows. This is caused by Judy's consistency in hiding her secrets or 
things kept inside herself. The feelings towards Jervis and hatred towards the Pendleton family are both kept inside by herself, this is proofed by the existence of them in all three Johari Windows. Judy never had an intention to open about it. The addition is Judy's discovery about her capability to be a writer. It is also considered into things she keeps inside. This is available in the third Johari Window.

Recapitulating those three Judy's Johari Windows development, the most dominant panel in the final result is her hidden area. Judy's fear of self-disclosure is portrayed in this widest hidden area which is now consisted of her identity, silly side, feelings for Jervis, hatred for Pendleton, and her capability to be a writer. Besides being in the hidden area, those are fulfilling the three operation requirements of selfconcealment; (1) a desire to keep things for oneself, (2) to avoid personal sharing of secrecy or unfavorable information, and (3) to be cautious of the disclosure of personal information concealed. (Cruddas et al., 2012). However, the hidden area as the most dominant panel overall Judy's Johari Window is backgrounded by fear of self-disclosure. Then, this fear of self-disclosure is attached with suppression, one type of defense mechanism (Larson et al., 2015).

Comparing with the previous studies, there are three similarities and one contrast. However, the first similarity found is about the queerness of the character. The queerness either in a vampire or a homosexual man can motivate them to do selfconcealment (Novenia, 2019; Oakley, 2012). This is considered similar to the queerness of an ex-orphanage who gets this stamp because of her ignorance or silliness. They conceal themselves because of avoiding judgment from people. This is proven by finding that Judy was always struggling to conceal her identity and her silliness. The second similarity is founded from the deception in a self-concealment. A study on Harry Potter novel characters found that self-concealment smooths their deception to complete their mission (Sangeetha, 2017). The deception also exists in Judy's identity management. Proven by finding of layered identity in Johari Window, she substitutes her true identity with a new faked identity to conceal the past self. The third similarity is according to consciousness. Previous studies found consciousness in doing self-concealment (Oakley, 2012; Sangeetha, 2017). A vampire is surely conscious when concealing his identity, by providing a new identity, like disguising himself to become a human, to be closer with his girlfriend. While, in Harry Potter novel characters, all of them are conscious in doing self-concealment, like Tom Riddle who disguises himself to become Voldemort to smooth his mission. In an exorphanage case, Judy is consciously doing self-concealment to disguise her past. This is proven by finding that Judy is manipulating her identity. While, one contrast pointed from a previous study of self-concealment in a homosexual man (Novenia, 2019). The study found that homosexual man does self-concealment as repression act. This means that he does it unconsciously. This is very different from the findings on Judy. She does it very voluntarily, in a conscious condition. By knowing the finding that self-concealment is previously founded as repression and now is suppression, this means that both are valid. 
This research has contributed to the world of literary psychology in general, and in the field of self-concealment in particular. In the world of literary psychology, new research spectacles can be formed and become a lot of related literature. On the psychological side, especially self-concealment, this can increase interpersonal communication and self-awareness.

\section{CONCLUSION}

The self-concealment of Judy Abbott is triggered by her fear of selfdisclosure. It is identified by how her Johari Window finally becomes dominated by the hidden area even though the open area had ever expanded. This means that Judy had been attempting to disclose herself to the public before decided to hide it. Judy's fear of self-disclosure is followed by deception and suppression. Thus, it leads her to the self-concealment because of suiting with its three operations. Then, Judy's selfconcealment is represented by her hiding and concealing her true identity, silliness, feelings for Jervis, hatred for Pendleton, and her capability to be a writer. Comparing with previous studies, Judy's self-concealment is suited with their findings. It is connected with queerness, deception, and consciousness which leads it into suppression. Judy's queerness can be found on her silliness, her deception is a new faked identity, and her consciousness is based on suppression in concealing her attempt to hide her silliness. But there is also one finding from a previous study that finds if the self-concealment can be attached with repression. Both repression and suppression are kinds of defense mechanism which lets the self-press the distressing personal information which its only difference is from unconsciousness or consciousness. In short words, the defense mechanism in self-concealment is depended on the doer.

\section{BIBLIOGRAPHY}

Chaudoir, S., \& Fisher, J. D. (2010). The Disclosure Processes Model. Psychological Bulletin, 136(2), 236-256. https://doi.org/10.1037/a0018193.

Cruddas, S., Gilbert, P., \& McEwan, K. (2012). The Relationship Between SelfConcealment and Disclosure, Early Experiences, Attachment, and Social Comparison. International Journal of Cognitive Therapy, 5(1), 28-37. https://doi.org/10.1521/ijct.2012.5.1.28

Hollander, A. F. (2015). The Fabian Child: English and American Literature and Socialist Reform, 1884-1915. Retrieved from https://escholarship.org/uc/item/2q169884

Khasanah, U. (2014). Coping Behavior For Unhappy Childhood In Jean Webster's Daddy-Long-Legs (1912): An Individual Psychological Perspective (Universitas Muhammadiyah Surakarta). Universitas Muhammadiyah Surakarta. Retrieved from http://eprints.ums.ac.id/30559/ 
Larson, D. G., \& Chastain, R. L. (1990). Self-Concealment: Conceptualization, Measurement, and Health Implications. Journal of Social and Clinical Psychology, 9(4), 439-455. https://doi.org/10.1521/jscp.1990.9.4.439

Larson, D. G., Chastain, R. L., Hoyt, W. T., \& Ayzenberg, R. (2015). Selfconcealment: Integrative review and working model. Journal of Social and Clinical Psychology, 34(8), 705-e774. https://doi.org/10.1521/jscp.2015.34.8.705

Luft, J. (1969). Of Human Interaction. Palo Alto, California: National Press Book. Retrieved from Google Scholar

Novenia, M. (2019). Elio's Defense Mechanisms in Concealing His Homosexuality in André Aciman's Call Me By Your Name (Universitas Sanata Dharma Yogyakarta). Universitas Sanata Dharma Yogyakarta. Retrieved from https://repository.usd.ac.id/34684/2/154214009_full.pdf

Oakley, S. (2012). "I Could Kill You Quite Easily, Bella, Simply by Accident."*: Violence and Romance in Stephenie Meyer's "Twilight" Saga (Minnesota State University). Minnesota State University. Retrieved from https://cornerstone.lib.mnsu.edu/etds/126/

Parse, R. R., \& Nursing, N. L. for. (2001). Qualitative Inquiry: The Path of Sciencing. Boston: Jones and Bartlett Publishers. Google Scholar

Rose Ragins, B., Singh, R., \& Cornwell, J. M. (2007). Making the Invisible Visible: Fear and Disclosure of Sexual Orientation at Work. Journal of Applied Psychology, 92(4), 1103-1118. https://doi.org/10.1037/0021-9010.92.4.1103

Sangeetha, D. R. (2017). Concealment as a Tool of Deception : An Analysis of J . K . Rowling 's Harry Potter and the Chamber of Secrets. NOTIONS, 8(1). Retrieved from https://journals.indexcopernicus.com/api/file/viewByFileId/576684.pdf

Webster, J. (2017). Daddy-Long-Legs (Second). Jakarta: Gramedia Pustaka Utama.

Wiresti, V. N. (2018). The Main Character's Personality Development in Jean Webster's Novel "Daddy Long Legs": A Psychological Study (University of Mataram). University of Mataram. Retrieved from http://eprints.unram.ac.id/2314/

Zhou, S., King, E. J., Gjorgiovska, J., Mihajlov, A., \& Stojanovski, K. (2019). Selfconcealment, discrimination, and mental health in Macedonia: Disparities experienced by sexual and gender minorities. Global Public Health, 14(8), 1075-1086. https://doi.org/10.1080/17441692.2018.1560484 